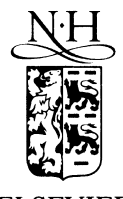

ELSEVIER

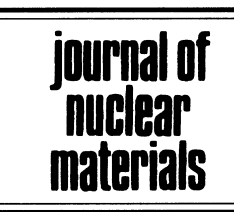

\title{
Long-term stability of ceramics in liquid lithium
}

\author{
B.A. Pint *, L.D. Chitwood, J.R. Di Stefano \\ Metals \& Ceramics Division, Oak Ridge National Laboratory, Oak Ridge, TN 37831-6156, USA
}

\begin{abstract}
Two candidate materials for insulating coatings in a lithium-cooled fusion reactor have been exposed to lithium in $1000 \mathrm{~h}$ isothermal tests from $400-800^{\circ} \mathrm{C}$ to determine their maximum compatibility temperature. Bulk samples of AlN $+5 \mathrm{wt} \% \mathrm{Y}_{2} \mathrm{O}_{3}$ showed significant mass loss at $600^{\circ} \mathrm{C}$ and higher temperatures. The amount of attack was reduced when $\mathrm{AlN}+0.04 \mathrm{wt} \% \mathrm{Y}$ was tested. Characterization by Auger spectroscopy of a $\mathrm{AlN}+0.04 \mathrm{wt} \% \mathrm{Y}$ specimen exposed at $600^{\circ} \mathrm{C}$ indicated the possibility of a lithium aluminate compound formation. Bulk, polycrystalline specimens of $\mathrm{CaO}$ (99.9\% purity) showed mass losses above $500^{\circ} \mathrm{C}$ indicating a possible dissolution problem that had not been observed in previous short-term screening tests and is not predicted based on thermodynamic calculations. Doping of the lithium with oxygen (in the case of $\mathrm{CaO}$ ) did not appear effective in reducing the mass loss at $600^{\circ} \mathrm{C}$. (C) 2000 Elsevier Science B.V. All rights reserved.
\end{abstract}

IDT: C03; C06; C08; E05; L03

\section{Introduction}

The blanket system in proposed deuterium/tritiumfueled fusion reactors converts the fusion energy into heat and breeds tritium for the fuel cycle. One promising blanket concept is the use of liquid lithium as the breeding medium, where the lithium also self-cools the blanket. However, in magnetic fusion energy systems where a strong magnetic field is used to contain the fusion plasma, a magneto-hydrodynamic (MHD) pressure drop is developed when the electrically conductive lithium flows across the magnetic field lines. Accordingly, an insulating barrier is needed to decouple the lithium and the vanadium alloy structure to allow the lithium to flow with acceptable pumping powers. From heattransfer considerations, this barrier must be relatively thin and integrally bonded to the first-wall containment material. The barrier or coating also must be resistant to radiation damage and, based on efficiency considerations, it must be compatible with the lithium and first wall at temperatures up to $\approx 700^{\circ} \mathrm{C}$.

\footnotetext{
${ }^{*}$ Corresponding author. Tel.:+1-423 576 2897; fax:+1-865 2410215.

E-mail address: pintba@ornl.gov (B.A. Pint).
}

Based on previous work [1-5], a limited number of insulating ceramics have been found to resist corrosion by lithium at $400-450^{\circ} \mathrm{C}$, e.g., $\mathrm{BeO}, \mathrm{MgO}, \mathrm{CaO}, \mathrm{Y}_{2} \mathrm{O}_{3}$, and AlN. However, many of these tests were conducted for $100 \mathrm{~h}$ or less. Since the operating temperature window for $\mathrm{V}-4 \mathrm{Cr}-4 \mathrm{Ti}$ is $400-700^{\circ} \mathrm{C}$ (due to low temperature radiation embrittlement and thermal creep) [6], it is essential to determine whether the candidate ceramic coatings have adequate corrosion resistance and electrical insulating properties after exposure to lithium at $400-700^{\circ} \mathrm{C}$. Also, since the design life of the reactor should exceed $25,000 \mathrm{~h}$, longer-term compatibility data are needed.

Thermodynamic calculations indicate that two of the promising candidates are $\mathrm{AlN}$ and $\mathrm{CaO}[3,4,7]$. Initial experimental work was conducted on bulk ceramics to determine maximum-use temperatures of AIN and $\mathrm{CaO}$. In this way, problems associated with coating fabrication could be separated from the fundamental issue of compatibility in lithium. Furthermore, because some investigators have reported complete loss of coatings during exposure to lithium, [8,9] testing bulk specimens allows for possibly high rates of dissolution to be measured. In general, the results are not promising for $\mathrm{CaO}$ or $\mathrm{AlN}+5 \% \mathrm{Y}_{2} \mathrm{O}_{3}$ at $600-800^{\circ} \mathrm{C}$; however, more work is 
required to better characterize the performance of $\mathrm{CaO}$ and $\mathrm{AlN}+0.04 \% \mathrm{Y}$ in this temperature range.

\section{Experimental procedure}

Two types of aluminum nitride were evaluated, one with nominally $5 \mathrm{wt} \% \mathrm{Y}_{2} \mathrm{O}_{3}$ (unless noted, all compositions are given in weight percent) from Goodfellow and the other with 400 wppm $\mathrm{Y}$ and $0.9 \mathrm{wt} \%$ oxygen from Tokuyama (Shapal SH-50). The AlN $+0.04 \% \mathrm{Y}$ material was produced by reducing and nitriding aluminum oxide and had a average grain size of 7-8 $\mu \mathrm{m}$. Both had a density of $3.25 \mathrm{~g} / \mathrm{cm}^{3}$. Specimens of $\mathrm{AlN}+5 \% \mathrm{Y}_{2} \mathrm{O}_{3}$ measured $\approx 0.6 \times 12 \times 12 \mathrm{~mm}$ while AlN $+0.04 \% \mathrm{Y}$ measured $\approx 2 \times 8 \times 12 \mathrm{~mm}$. Calcium oxide $(99.9 \%$ purity) was obtained from Cerac in the form of a sputtering target that was cut into specimens approximately $\approx 6 \times 6 \times 13 \mathrm{~mm}$. To avoid degradation from reaction with moisture, $\mathrm{CaO}$ was cut with a diamond blade and handled in dry air or in an argon glove box before and after testing. Dimensions and mass were measured before and after exposure with an accuracy of $0.02 \mathrm{mg} / \mathrm{cm}^{2}$.

For exposure to lithium, each ceramic specimen was placed in individual capsules of $\mathrm{V}-4 \mathrm{Cr}-4 \mathrm{Ti}$ measuring $\approx 25 \mathrm{~mm}$ O.D. $\times 76 \mathrm{~mm}$ long. High purity solid lithium (starting composition in Table 2) was top loaded into the capsules in an argon glove box and the capsules were sealed using gas-tungsten-arc welding. In two tests, ad-

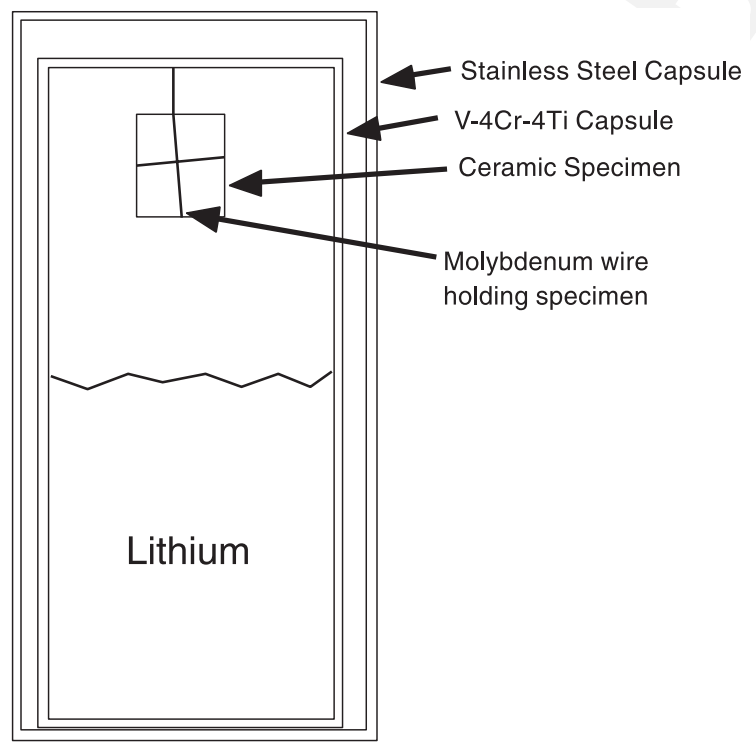

Fig. 1. Schematic of the ORNL Li capsule test. The specimen was attached to one end of the $\mathrm{V}-4 \mathrm{Cr}-4 \mathrm{Ti}$ by a wire. At the end of the test, the capsule was inverted to free the specimen from the lithium for removal. ditions of $\mathrm{Li}_{3} \mathrm{~N}$ and $\mathrm{Li}_{2} \mathrm{O}$ were made to increase the impurity levels in the lithium to nominally $1000 \mathrm{ppm}$ of nitrogen or oxygen. The specimens were held in place at the lower end of the capsules by a molybdenum wire attached to the inside of the capsule. (Molybdenum is resistant to dissolution in lithium [10].) A second sealed container of stainless steel was used to protect the V$4 \mathrm{Cr}-4 \mathrm{Ti}$ from oxidation during the test, Fig. 1. Capsules were placed in calibrated box furnaces for $1000 \mathrm{~h}$ at temperatures from $400-800^{\circ} \mathrm{C}$. At the end of the test, the capsules (still at temperature) were removed from the furnace and inverted to allow the molten lithium to drain into the opposite end of the capsule from the specimen. However, because of surface tension, some amount of lithium always adheres to the specimen. After testing, the capsules were opened in an argon glove box, the specimens removed, and samples of lithium taken for spectrographic chemical analysis at Lockheed Martin Energy Systems, Oak Ridge, TN. The ceramic sample was sealed into a distillation apparatus in the argon glove box before being removed for vacuum distillation at $500-600^{\circ} \mathrm{C}$. In some cases, a final alcohol cleaning of AlN (but not $\mathrm{CaO}$ ) was done to remove any residual lithium or distillation residue. However, it was determined that this left a carbon residue on the specimen and inhibited further characterization. Initial characterization has been performed on selected specimens. In order to detect lithium, Auger electron spectroscopy (AES) was used to examine the specimens after exposure. Because of the heavy attack on many of the specimens, electrical resistance measurements have not yet been made.

\section{Results and discussion}

Mass changes after the $1000 \mathrm{~h}$ exposures to lithium are shown in Table 1. Both materials have similar densities; thus a uniform mass loss of $\approx 3.2 \mathrm{mg} / \mathrm{cm}^{2}$ corresponds to a $10 \mu \mathrm{m}$ loss in material thickness. However, some of the mass change results were confounded by the inadvertent use of Ni wire (rather than Mo wire) to restrain the specimens in the capsule. This resulted in some nickel being deposited on the surface of the ceramic specimen (determined by AES) due to dissolution of the wire. The amount of deposition appeared to increase with temperature with little $\mathrm{Ni}$ observed at $400^{\circ} \mathrm{C}$.

At $400^{\circ} \mathrm{C}$, the mass changes were small for all of the materials tested which is in agreement with previous 100 $\mathrm{h}$ tests at $400^{\circ} \mathrm{C}[1]$ and $450^{\circ} \mathrm{C}$ [2]. For AlN $+5 \% \mathrm{Y}_{2} \mathrm{O}_{3}$, a significant mass loss was measured at $600^{\circ} \mathrm{C}$ and only small bits of specimen were recovered after the $700^{\circ} \mathrm{C}$ exposure. The mass gain at $500^{\circ} \mathrm{C}$ was in part due to $\mathrm{Ni}$ deposition on the specimen. After testing, the lithium showed an increase in aluminum content with test temperature possibly indicating some dissolution of 
Table 1

Mass changes of bulk ceramic specimens after $1000 \mathrm{~h}$ exposures to lithium at various temperatures

\begin{tabular}{|c|c|c|c|c|c|c|}
\hline \multirow[t]{2}{*}{ Conditions } & \multicolumn{2}{|c|}{$\mathrm{AlN}+5 \% \mathrm{Y}_{2} \mathrm{O}_{3}$} & \multicolumn{2}{|c|}{$\mathrm{AlN}+0.04 \% \mathrm{Y}$} & \multicolumn{2}{|l|}{$\mathrm{CaO}$} \\
\hline & $\%$ & $\mathrm{mg} / \mathrm{cm}^{2}$ & $\%$ & $\mathrm{mg} / \mathrm{cm}^{2}$ & $\%$ & $\mathrm{mg} / \mathrm{cm}^{2}$ \\
\hline $400^{\circ} \mathrm{C}$ & $-0.18^{a}$ & $-0.17^{\mathrm{a}}$ & $+0.1^{\mathrm{a}}$ & $0.23^{\mathrm{a}}$ & $+0.08^{\mathrm{a}}$ & $0.22^{\mathrm{a}}$ \\
\hline $500^{\circ} \mathrm{C}$ & $+1.7^{\mathrm{a}}$ & $+1.9^{\mathrm{a}}$ & $+1.05^{\mathrm{a}}$ & $2.4^{\mathrm{a}}$ & $-3.1^{\mathrm{a}}$ & $-8.56^{\mathrm{a}}$ \\
\hline $600^{\circ} \mathrm{C}$ & -1.9 & -1.8 & +0.1 & +0.26 & -3.6 & -10.3 \\
\hline $\begin{array}{l}600^{\circ} \mathrm{C}+1000 \\
\text { ppm N }\end{array}$ & & & +0.6 & +1.36 & & \\
\hline $\begin{array}{l}600^{\circ} \mathrm{C}+1000 \\
\text { ppm O }\end{array}$ & & & & & -3.3 & -9.51 \\
\hline $700^{\circ} \mathrm{C}$ & \multicolumn{2}{|c|}{ Specimen broke } & $+5.4^{\mathrm{a}}$ & $+12.5^{\mathrm{a}}$ & $-2.7^{\mathrm{a}}$ & $-7.18^{a}$ \\
\hline $800^{\circ} \mathrm{C}$ & \multicolumn{2}{|c|}{ Not tested } & -8.6 & -26.5 & -8.0 & -23.3 \\
\hline
\end{tabular}

${ }^{\mathrm{a}}$ Specimen suspended by $\mathrm{Ni}$ wire which dissolved and redeposited on specimen during testing.

Table 2

Lithium compositions for $\mathrm{AlN}+5 \% \mathrm{Y}_{2} \mathrm{O}_{3}$ tests determined by spectrographic analysis

\begin{tabular}{llll}
\hline Conditions & Nitrogen (wppm) & Aluminum (wppm) & Yttrium (wppm) \\
\hline Starting lithium ${ }^{\mathrm{a}}$ & 244 & $<10$ & $<6$ \\
After $1000 \mathrm{~h}$ at $400^{\circ} \mathrm{C}$ & 292 & 800 & $<6$ \\
After $1000 \mathrm{~h}$ at $600^{\circ} \mathrm{C}$ & 232 & 1500 & $<6$ \\
After $1000 \mathrm{~h}$ at $700^{\circ} \mathrm{C}$ & 258 & $>4000$ & $<6$ \\
\hline
\end{tabular}

${ }^{\text {a }}$ Of 40 metallic elements examined, only $\mathrm{Cu}(15 \mathrm{wppm})$ was above detectability limit.

$\mathrm{AlN}+5 \% \mathrm{Y}_{2} \mathrm{O}_{3}$ at all temperatures and major dissolution at $700^{\circ} \mathrm{C}$, Table 2. The nitrogen content of the lithium did not significantly increase during the test. This may indicate that the $\mathrm{V}-4 \mathrm{Cr}-4 \mathrm{Ti}$ capsule walls gettered some of the nitrogen. It is possible that the source of the $\mathrm{Al}$ was the dissolution of the $\mathrm{Y}_{3} \mathrm{Al}_{5} \mathrm{O}_{12}(\mathrm{YAG})$ grain boundary phase from the AlN $+5 \% \mathrm{Y}_{2} \mathrm{O}_{3}$ specimen, but comparable levels of $\mathrm{Y}$ were not detected in the lithium (Table 2). Previous work showed slightly higher mass loss of $\mathrm{Y}_{2} \mathrm{O}_{3}$ and YAG than AlN in lithium at $400^{\circ} \mathrm{C}$ [1]. Regardless of what is dissolving, the high $\mathrm{Al}$ levels in the lithium indicate that some reaction is taking place. In order to avoid the complication of the YAG phase, additional tests were performed on $\mathrm{AlN}+0.04 \% \mathrm{Y}$. Also, because of the severe attack of the $0.6 \mathrm{~mm}$ thick specimen at $700^{\circ} \mathrm{C}$, a minimum 2-mm thick specimen was chosen.

The results for AlN $+0.04 \% \mathrm{Y}$ showed mass gains up until $800^{\circ} \mathrm{C}$ where a large mass loss was measured, Table 1. However, the mass gain at $500^{\circ} \mathrm{C}$ and $700^{\circ} \mathrm{C}$ was in part due to a visible Ni deposition. Examination of the AlN surface after exposure at $500^{\circ} \mathrm{C}$ by AES showed $70 \%$ of the signal from Ni. When a Mo wire was used for testing at $600^{\circ} \mathrm{C}$, a slight mass gain was observed for $\mathrm{AlN}+0.04 \% \mathrm{Y}$, rather than the mass loss observed for AlN $+5 \% \mathrm{Y}_{2} \mathrm{O}_{3}$. It appears that changing the $\mathrm{Y}$ content had a significant effect on performance. A higher mass gain was observed for AlN $+0.04 \% \mathrm{Y}$ when $1000 \mathrm{ppm}$ nitrogen was added to the lithium (Table 1), but the specimen appeared to have a thicker residue on the surface that was not removed by distillation. The addition of nitrogen was made in an attempt to increase the activity of nitrogen in lithium and thereby limit any dissolution reaction.

The $\mathrm{AlN}+0.04 \% \mathrm{Y}$ specimen exposed to lithium at $600^{\circ} \mathrm{C}$ (followed by distillation at $500-600^{\circ} \mathrm{C}$ was sputter depth profiled by AES in order to characterize the reaction product. Fig. 2 shows a complex distribution of elements to a depth of almost $2 \mu \mathrm{m}$, below which there appeared to be largely $\mathrm{Al}$ and $\mathrm{N}$ present. There appeared to be an outer layer (labeled I) of mainly Li and $\mathrm{O}$ and a

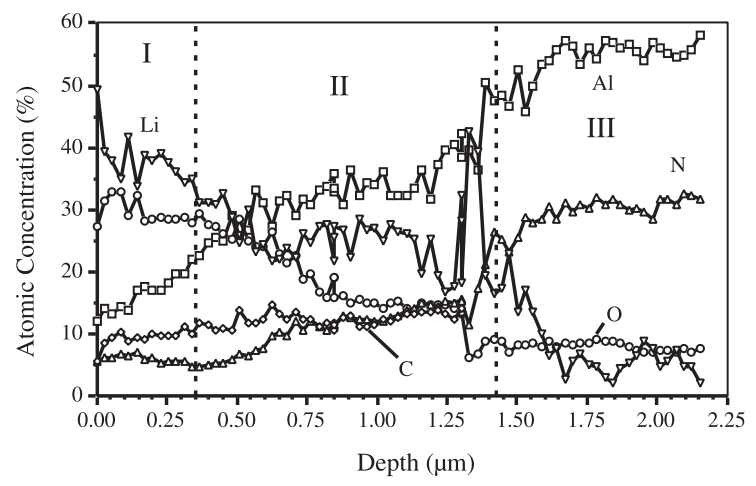

Fig. 2. Sputter depth profile from the surface of AIN $+0.04 \% \mathrm{Y}$ after $1000 \mathrm{~h}$ at $600^{\circ} \mathrm{C}$ determined by Auger electron spectroscopy. A layer of largely Li and O (I) was observed above a layer with large amounts of $\mathrm{Li}, \mathrm{Al}$ and $\mathrm{O}$ (II). Further sputtering appeared to reveal the substrate (III). 
second layer (II) where there were large amounts of $\mathrm{Li}$, $\mathrm{Al}$ and $\mathrm{O}$ above the substrate (III). This indicates that there is probably a reaction where the AlN is transforming to an oxide, such as lithium aluminate. The specimen exposed at $800^{\circ} \mathrm{C}$ showed a surface composition of 42 at. $\% \mathrm{O}-32 \% \mathrm{Al}-12 \% \mathrm{Li}-14 \% \mathrm{C}$ beneath a patchy layer of $\mathrm{Li}-\mathrm{C}-\mathrm{O}$ which appeared to spall off of some areas. (Lithium exposed to air will readily form a carbonate.) In this case, it was believed that the oxygen-rich layer was too thick to be sputtered through by AES. The presence of an aluminate reaction product could degrade the electrical properties of the coating and lithium aluminate has been shown to dissolve in $\mathrm{Li}$ at $450^{\circ} \mathrm{C}$ [2].

The source of the oxygen in the Li-containing reaction layer (Fig. 2) could be the AlN-0.04Y material (0.9 $\mathrm{wt} \%$ oxygen), impurities in the lithium or the vanadium capsule. Any oxygen present in the $\mathrm{V}-4 \mathrm{Cr}-4 \mathrm{Ti}$ is likely to be gettered by the lithium [11]. However, oxygen diffusion in $\mathrm{V}-4 \mathrm{Cr}-4 \mathrm{Ti}$ would be relatively slow at temperatures below $600^{\circ} \mathrm{C}$. More testing is required to confirm this behavior over the temperature range 500$700^{\circ} \mathrm{C}$ and additional characterization by X-ray diffraction is warranted. Confirmation is extremely important because a thin AlN MHD coating may be substantially attacked by a similar process in a flowing lithium system. The change in electrical properties of AlN after exposure to lithium may indicate the severity of this problem. Since $\mathrm{Al}_{2} \mathrm{O}_{3}$ is not compatible with lithium [1], the presence of oxygen in the outer layer suggests that further efforts may be required in order to avoid oxidation of AlN.

The mass change data for $\mathrm{CaO}$ indicate that there was little interaction with lithium at $400^{\circ} \mathrm{C}$ (Table 1), which is in agreement with previous experimental work $[1,2]$ and thermodynamic calculations $[3,4,7]$. However, at $500-800^{\circ} \mathrm{C}$, significant mass losses of $\mathrm{CaO}$ were recorded that generally increased with temperature (Table 1). These specimens were very brittle, and some mass loss may have resulted from small pieces breaking off. However, the consistency of the losses and similar general appearance of the specimens after testing suggested that these results are accurate and that substantial reaction occurred at higher temperatures. Analysis of the lithium after these exposures did show an increase in the amount of calcium in the lithium (Table 3). However, it is not possible by routine analytical techniques to mea-

Table 3

Lithium compositions for $\mathrm{CaO}$ tests determined by spectrographic analysis

\begin{tabular}{ll}
\hline Conditions & Calcium (wppm) \\
\hline After $1000 \mathrm{~h}$ at $400^{\circ} \mathrm{C}$ & 96 \\
After $1000 \mathrm{~h}$ at $500^{\circ} \mathrm{C}$ & 206 \\
After $1000 \mathrm{~h}$ at $700^{\circ} \mathrm{C}$ & 314 \\
\hline
\end{tabular}

sure the oxygen content of lithium. An attempt was made to increase the activity of oxygen in the lithium in order to decrease the rate of dissolution. However, with the addition of $1000 \mathrm{ppm} \mathrm{O}$ to the lithium a higher mass loss was measured after exposure at $600^{\circ} \mathrm{C}$. Due to charging problems, $\mathrm{CaO}$ specimens could not be analyzed by AES or X-ray photoelectron spectroscopy (XPS) making it very difficult to look for the presence of $\mathrm{Li}$ on the surface of these specimens.

It has been noted that thermodynamic calculations $[3,4,7]$ indicate $\mathrm{CaO}$ and $\mathrm{AlN}$ should not be reduced by lithium and, therefore, should be good candidate MHD coating materials at the temperatures of interest. However, the present results for polycrystalline $\mathrm{CaO}$ and AlN $+0.04 \% \mathrm{Y}$ do not confirm these predictions. The calculations rely on a small data set of thermodynamic data and do not consider possible effects of the $\mathrm{V}-4 \mathrm{Cr}-$ $4 \mathrm{Ti}$ container. Follow-on testing of single crystal $\mathrm{CaO}$ is planned to further study the compatibility of $\mathrm{CaO}$ in lithium at $500-700^{\circ} \mathrm{C}$ in order to eliminate the possible effect of grain boundary impurities on the reaction with lithium.

\section{Summary}

Initial long-term $(1000 \mathrm{~h})$ testing and characterization of $\mathrm{AlN}$ and $\mathrm{CaO}$ in lithium indicated that bulk, polycrystalline $\mathrm{CaO}$ reacts with lithium and significant mass losses were measured above $400^{\circ} \mathrm{C}$. Significant mass losses also were observed for $\mathrm{AlN}+5 \% \mathrm{Y}_{2} \mathrm{O}_{3}$ above $500^{\circ} \mathrm{C}$, so subsequent testing focused on AlN $+0.04 \% \mathrm{Y}$, which appeared more resistant to reaction with lithium. However, at $600^{\circ} \mathrm{C}, \mathrm{AlN}+0.04 \% \mathrm{Y}$ appeared to form an oxide at the surface which could be deleterious to the performance of a thin AlN MHD coating. Further testing and characterization is necessary to determine the extent of this attack.

\section{Acknowledgements}

The research was sponsored by the Fusion Energy Materials Program, US Department of Energy (DOE), under contract DE-AC05-00OR22725 with UT-Battelle, LLC. D. Braski at ORNL assisted with the AES work and J. King supervised the welding of the test capsules. J. H. DeVan, A. F. Rowcliffe, P. F. Tortorelli and S. J. Zinkle provided comments on the manuscript.

\section{References}

[1] R.J. Lauf, J.H. De Van, J. Electrochem. Soc. 139 (1992) 2087. 
[2] J.E. Battles, Intern. Mater. Rev. 34 (1989) 1.

[3] I. Schreinlechner, F. Holub, in: H. U. Borgstedt (Ed.), Materials Behavior and Physical Chemistry in Liquid Metal Systems, Plenum, NY, 1982, pp. 105.

[4] R.N. Singh, J. Amer. Ceram. Soc. 59 (1976) 112.

[5] J.H. Park, T.F. Kassner, J. Nucl. Mater. 233-237 (1996) 476.

[6] E.E. Bloom, J. Nucl. Mater. 258-263 (1998) 7.

[7] P. Hubberstey, T. Sample, J. Nucl. Mater. 248 (1997) 140.
[8] K. Natesan, Argonne National Laboratory, unpublished results, 1999.

[9] S. Sastri, Surmet, Burlington, MA, SBIR final report to the Department of Energy, contract \#DE-FG02-98ER82678.

[10] E.E. Hoffman, J.H. DeVan, J.R. DiStefano, in: E.N.C. Dalder, T. Grobstein, C.S. Olsen (Eds.), Evolution of Refractory Metals and Alloys, TMS, Warrendale, PA 1994, pp. 137.

[11] J.H. De Van, R.L. Klueh, Nucl. Technol. 24 (1974) 64. 